\title{
A Doctor in the House: Looking for New Insights on Mahathir's Islamisation Policy in His Memoirs
}

\author{
Osman Bakar*
}

The role of the state in Malaysia through its elected government of the day in promoting and regulating Islam has been visible from day one of the country's new life as an independent nation. Even before independence in 1957, particularly for those states of the Malaysian Federation that have Sultans or Rulers, the public visibility and role of Islam has always been an integral part of the Malay-Muslim societal life. There is continuity between the pre-independence public profile of Islam and the post-independence one.

In several of my earlier writings, I maintained the view that with independence from Britain in 1957, the public role of Islam has been progressively expanding and widening. The most important factor that contributed to this very significant societal change in Malaysian national life is perhaps the Islam policy of each of the elected governments since independence. I maintain that it is possible to identify each of the National Administrations of the five Prime Ministers preceding Dato' Sri Mohd Najib Tun Abdul Razak with an Islam-policy of some sort. ${ }^{1}$ It is this Islam-policy that seeks among others to enhance the public role of Islam in such a way and to such an extent that would both meet the religious aspirations of the Malay-Muslim community and serve the political interests of the dominant ruling party, UMNO.

Of all the Islam policies of Najib's predecessors, the one identified with the Mahathir Administration is easily the most comprehensive, the most impactful on Malaysian society, and also the most controversial. The core element of Mahathir's Islam-policy is what is popularly known as the 'Islamisation-policy' which sought to ensure that no laws of the country and no government policies would be in conflict with the teachings of Islam. The controversy to which I have just referred surrounds mainly the issue of the 'Islamisation-policy', and it arose largely from the non-Muslim dissatisfaction with the policy. Many non-Muslims opposed the 'Islamisation-policy' because they viewed it, as they still do, as an imposition of Islamic ideas and values on the general public of which the non-Muslims are a substantial part.

Mahathir today is no longer in power. With his exit from the corridors of power his 'Islamisation-policy' disappeared from the screen of government policies. However, the issue of 'Islamisation' has not totally disappeared from the Malaysian public mind. It is still very much a living issue in the minds of many Muslims, especially among the proponents and supporters of the policy. And it is a lingering concern among the

* Osman Bakar is the Deputy CEO of IAIS Malaysia and Emeritus Professor of Philosophy of Science at the University of Malaya, Kuala Lumpur. 
non-Muslims. They often cite 'Islamisation' as their real concern whenever they are asked about the challenge of 'official' Islam to the non-Muslim communities and the future of their respective religions. Many non-Muslims are blaming 'Islamisation' for the current religious tension between Muslims and non-Muslims in the country. Every now and then, we would come across international media coverage on the issue of interreligious tension in Malaysia, particularly that involving Muslims and Christians that attributes to non-Muslims views blaming 'Islamisation' as the main contributory factor to the tension in question.

Then there are the academics mainly from outside Malaysia, both Muslims and non-Muslims, who are continuing to keep a strong interest on the issue of 'Islamisation' in the country. I myself have been approached to this day by these academics either to write papers for seminars and conferences evaluating the impact of 'Islamisation' on Malaysian public life or to review their writings on the same subject. ${ }^{2}$ Indeed, I cannot imagine how the issue of 'Islamisation', given its contentious nature and intellectually speaking, given its hardly resolved status, could ever disappear from the Malaysian public mind. I believe the issue of Islamisation will drag on, at least in certain circles and among some groups and organisations, for some time to come.

This is the likely future scenario, because for Muslims, the meaning and significance of 'Islamisation' goes beyond that of Mahathir's 'Islamisation' policy. For the Muslim community (ummah) in Malaysia as is true elsewhere, there is another understanding of 'Islamisation' - I call it 'ummatic Islamisation' - which cannot be simply equated with Mahathir's government policy bearing that name. 'Ummatic Islamisation' is not seasonal or periodic, but perennial in nature and it is an on-going developmental process that is rooted in the very identity of the Muslim umma and that exteriorises the 'tawhidic' spirit of Islam and the inner dynamism of Islamic law (the shari 'ah) which characterise the 'ummatic' identity.

'Ummatic Islamisation' thus understood represents the collective work of the Malaysian Muslim umma. It does not belong to any government nor does it belong to any political party. It is the collective response of the ummah to cater to its collective needs and to confront its collective challenges. It has been part of the Malay-Muslim community life long before Mahathir adopted 'Islamisation' as his government policy. I am confident that it will survive Mahathir's 'Islamisation-policy' and continue to be an important part of Malaysian Muslim religious life. I know that as I am writing these words some groups somewhere in the country are planning to organise seminars and conferences on the theme of 'Islamisation', including on the more specific theme of 'Islamisation' of knowledge which has aroused much controversy in the past, even among the Muslims.

If many Muslims have given support to Mahathir's 'Islamisation-policy' before, it is mainly because they found many aspects of the policy to be in conformity 
with the spirit of the pre-existing 'ummatic Islamisation' that they had seen earlier, experienced and supported. They were certainly appreciative of the many good fruits of the policy that are clearly visible to this day in such public domains as higher education, law, economics and finance. The International Islamic University in Gombak, Islamic banking and finance institutions, and the upgrading of the shari 'ah court system are some of the most significant institutional achievements of the Mahathir Administration. These are highly prized not only by Mahathir's political supporters, but by the whole Muslim community.

Mahathir is aware that all these Islamic institutional achievements have been possible thanks largely to his 'Islamisation-policy'. He is proud of these achievements which form important parts of his legacy to the nation. Thus he defends his 'Islamisation-policy' in his memoirs entitled A Doctor in the House: The Memoirs of Tun Dr Mahathir Mohamad. ${ }^{3}$ He devotes a chapter of the book to the subject of Islam and 'Islamisation' which is also the title of the chapter (chapter 36, pp. 477-94). However, only a very small part of the chapter - just two paragraphs out of 17 pages - makes explicit references to 'Islamisation' and the national adoption of Islamic values which is its core content.

In one paragraph (p. 479), he writes: "Islam and the Islamisation of the Malaysian administration were not causes of contention before. What is a fact is that during the period when Malaysia adopted Islamic values and declared itself an Islamic country, there was peace and stability and the country developed and grew as never before." The other paragraph in question (p. 492) has this to tell us: "When I decided to give more meaning to the constitutional provision that Islam is the official religion, I did not mean that all the different peoples of Malaysia must become Muslim. All we wanted was that Islamic values be imbibed by Malaysians without the need for them to even believe in Islam. And so it was that in my second year as Prime Minister I declared that the Malaysian government would be guided by Islamic values."

The two paragraphs do not reveal anything new about Mahathir's 'Islamisationpolicy' that the public has not yet known. However, it is significant that in his memoirs published about eight years after his retirement from office, he defends the policy as something that is good for the whole nation and not just for the Muslim community, citing also what has motivated and inspired him to embark on the policy. In his testimony it is out of personal conviction, and not political expediency, that he decided to adopt and pursue the 'Islamisation' of the country's administration as a major pillar of his government policies. He strongly believes that Islamic values by virtue of its universal nature are good for all human beings. So he wants these values to be imbibed by Malaysians, without them, that is if they are non-Muslims, having to convert to Islam. He contends that during his rule of over two decades, when Malaysia adopted Islamic values, the country enjoyed "peace and stability", and it "developed and grew as never before". 
The rest of the chapter is useful for us to understand how Mahathir arrived at his conviction about the universal goodness of Islamic values and of the need to put them into practice in Malaysian societal life, at least at the level of national administration. It is essentially a description of the place of Islam in his intellectual autobiography and his own understanding of Islam as a tolerant and progressive religion which he contrasts with what he calls the "intolerant, rigid and strict" interpretation of Islam (p. 480). It is interesting to note that Mahathir saw the constitutional provision of Islam as the official religion as a golden opportunity for him as the leader of the country to give practical shape and societal expressions to the Islamic values he believes to be universally good to all Malaysians. In so doing he sends the message that his 'Islamisation-policy' is nothing more than an attempt to make the position of Islam as the official religion more meaningful and to make Islamic values the source of the common good for all Malaysians.

\section{Recommendations}

In concluding, I would like to argue that

- there is a need to have a fuller account of the impact of Mahathir's 'Islamisation-policy' on the Malaysian discourse on Islam for the simple reason that the real meaning of Islam as the official religion has of late generated more intense disputes than ever before, thereby contributing to a wider divide between the Muslims and non-Muslims.

- In conformity with the spirit of our present times, we appeal for enlightened dialogues on this very important national issue.

\section{Notes}

1. For a more detailed discussion of these Islam policies, see Osman Bakar, "Identifying the Islam Policies of the Predecessors of the Najib Administration: Has He Abandoned Tradition?" Islam and Civilisational Renewal 2, no. 4 (July 2011), 723-26.

2. For one of these invited papers on 'Islamisation' in Malaysia, see Osman Bakar, "Religious Reform and the Controversy Surrounding Islamization in Malaysia," in: Syed Farid Alatas (ed.), Muslim Reform in Southeast Asia: Perspectives from Malaysia, Indonesia, and Singapore (Singapore: Islamic Religious Council of Singapore, 2009), 31-45.

3. Mahathir Mohamad, A Doctor in the House: The Memoirs of Tun Dr Mahathir Mohamad (Petaling Jaya [Malaysia]: MPH Publishing, 2011). 